\title{
Kossuth Lajos és a színház
}

Bármennyire is bizarrnak hathat nemzetkarakterológiánk megtestesítöjeként és történelmünk formálójaként számon tartott Kossuth Lajos és a feslett kulisszák világaként emlegetett müvelödési ágazat kapcsolatáról szólni, megállapíthatjuk, hogy Kossuth ,politika csinálás"-ában a színház müfaja fontos szerepet töltött be. Az nem lenne természetes, ha ez másként lenne, hisz a színjátszás erdélyi prófétája, Kótsi Patkó János mondotta, hogy „...a szív formálására és a nemzet karakterének jobbítására vagy elrontására is a játékszínnél alkalmatosabb eszközt még az emberi elme fel nem talált." Valóban, a magyar színjátszás a felvilágosodás korában az erkölcsnemesítés és nyelvápolás intézményeként születik meg, $\mathrm{s}$ mi sem kézenfekvöbb, hogy a reformkorban a színház, a tömegekre hatás, a politikai mozgósítás hatékony eszközeként bekapcsolódik a nemzet „tsinosodásáért” folytatott küzdelembe.

Színháztörténészek szerint már az ifjú Kossuth irodalmi érdeklödésének körébe vágott a színpadi munkásság. Ha nem is bizonyítottan, de fordításokat, eredeti drámákat tulajdonítottak neki. (Pl. Kossuth fordításának tartják a debreceni színházban elő is adott Karl Haffner müvet, az Egy államférfi vagy az igazságos miniszter címüt, illetve saját alkotásként kezelték a több városban is bemutatott András és Béla vagy Korona és Kard címủ drámát).

1838-ban mutatták be Szigligeti példázat drámáját, a Pókaiak-at, $\mathrm{s}$ az előadás eszméinek hatására nézötéri tulntetés tört ki az erdélyi unió és az országgyülési ifjak, Kossuth Lajos és Wesselényi Miklós pere mellett. Ebben a vonatkozásban kell szólnunk Csabai Tibor kutatásaira alapozva a színi mozgalom hatásáról Kossuth személyiség fejlödésére. Börtönévei alatt szisztematikusan olvassa a magyar és világirodalom drámai alkotásait ( pl. Hugo Ruy Blas-át, Addison Cato-tragédiáját), Shakespeare-t fordít ( a Macbeth-et), s pályája folyamán kiderül, hogy ez a munkássága nem csak nyelvgyakorlatnak volt jelentős, hanem szellemi pallérozás szempontjából is fontos volt, hisz későbbi politikai-publicisztikai tevékenysége folyamán érv rendszerének fontos eleme volt a színmüirodalmi hivatkozás. Börtönleveleiben véleményt nyilvánít a színi életet akkor foglalkoztató vitáról: „, Mi befolyása van a drámai literatúrának a nemzet erkölcsi életére? S miért nálunk magyaroknál oly kevés eddig az eredeti drámai munka?" - kérdésre kimerítỏ választ ad. Kossuth politikai harcainak tetőzésekor is, aki a Felelet Gróf Széchenyi Istvánnak Kossuth Lajostól címủ munkájában oly nagy hangsúlyt helyez az érdekegyesítésre, s ennek eszközeként nagy szerepet tulajdonít az agitációnak, a közvélemény teremtésnek, a tömegek megnyerésének, elismeri, hogy a nemzet színháza mindezek elérésére legfontosabb közintézményeink egyike, $s$ a politikai küzdelmek egyik lényeges vonatkozásának tartja, hogy vezetőjẻnek a reformellenzék egyik kiemelkedö személyiségét, gróf Rádayt nevezzék ki. Többekkel együtt, Batthyảny Lajossal, Teleki Lászlóval több izben aláirja a Ráday védelmében szerkesztett beadványt. Kossuth politikai eszköztárában olyannyira fontosnak tartja a Pesti Színház jó menetelét, hogy Vörösmartyval együtt, még a színészek gázsi emelési vitájában is felszólal. A forradalom alatt Kossuth a kormány pénzügyminisztereként gondoskodik arról, hogy a költségvetés 20000 pengöforintot irányozzon elö a Nemzeti Színház müködtetésére. A színház a forradalmárok és a vezetők együtt ünneplésének színterévé válik. Az 1849-es diadalmas tavaaszi hadjárat idején április 28-án Aulich, 29-én Klapka, majd június 9-én maga Kossuth vešz részt a Nemzeti Színház elöadásain. A közhangulat fokméröjévé is vált nemzeti közintézményünk. Az 1849. február 16-i elöadáson a karzat Kossuth Lajost éltette. Megállapítható tehát, hogy 
ebben a korszakban a színi mozgalom, mint a szív formálója és a nemzet karakterének jobbítója, a történelem fösodrában, a kossuthi eszmevilág kifejezöje és harcosa volt.

Eszmefuttatásomat azzal kezdtem, hogy a Kossuth-jelenség nemzetkarakterológiánk kifejezője, s mint ilyen a nemzeti sorskérdéseket felvállaló színjátszás nyersanyagának számító történelmi nemzeti dráma hőseként is meg kell jelennie.

Erre a münem hagyománya is kötelezte színi irodalmunk alkotóit, miszerint a mi tájainkon a történelmi események megidézése egyben példázat is az író kora felvetette dilemmák feloldási alternatíváiról.

Elevenítsük fel vázlatosan ezt a hagyományt. Az iskolai színjátszás ihlette az első történelmi drámák létrejöttét. Az enyedi kollégiumban, a 17. század második felében keletkezett protestáns iskoladráma, a Komédia a törökők és magyarok csatảjáról, a kenyérmezei ütközet felelevenítése kapcsán már kora problémáit is érinti. A francia klasszicizmus dramaturgiai elveinek büvkörében fogant Bessenyeiféle történelmi játék, a Hunyadi László is, a felvilágosodás korában, a nemzeti kultúra megteremtésének ủgyét szolgálja. A továbbiakban a 19. század történelmi drámái kifejezetten a reformeszmék szolgálatában a nemzeti kiteljesedés eszméjének diadalát kívánták elösegíteni. Katona József Bánk bánja, Kisfaludy Károly Stibor vajdája, Vörösmarty Czillei és a Hunyadiakja, Teleki László Kegyence a korproblémák parabolái is. A huszadik századi magyar történelmi dráma elsörendủen parabolisztikus fogantatású. Herczeg Ferenc klasszicista romantikuspatetikus színmủvei, Szomory Dezső stilizált impresszionista drámái, Márai, Füst, Kodolányi, Háy színpadra szánt írásai, mind-mind történelmi jelmezbe öltöztetett eszmefuttatás kortársi gondokról. A század második felétöl kezdỏdően Németh, Illyés, Sütő, Szabó Magda, Székely, Páskándi, folytatva a történelemhez aktívan viszonyuló hösök sorának ábrázolását, a totalitarista rendszer szorításában már vizsgálják a hatalom természetrajzát, az egyén cselekvési lehetỏségeit is. A huszadik század végén azonban eluralkodnak az identitásvesztés színpadi müvei s a történelmi dráma klasszikus modellje helyét átveszi a történelmi parabola ironikus-groteszk hangvétele.

De lássuk Kossuth és az általa teremtett eszmekör konkrét hatását drámatermésünben, színpadi előadásainkban. Általában kell megállapítanunk, hogy a magyar nyelvterületen színházaink valahányszor hazafias érzelmeiket kívánták kinyilvánítani, Kossuth alakját idézték, akár alkalmi játékok formájában is. Erre a modellre jó példa a Szabadkán, a múlt század utolsó harmadában bemutatott, Kossuth búcsúja Orsovánál címü színpadi mü. Kossuth életre keltésének másik modellje, a nemzeti felújulás idỏszakában a XIX. század utolsó négy évtizedében, a történelmi allegóriảk, az életképek színrevitele. İgy például Nagyváradon 1861-ben az ott szereplő Latabár Endre társulata " egy nagy történelmi allegória keretében" léptet színre egy Kossuth maszkot viselő színészt.

Az 1848-as forradalom eseményeinek kossuthi szemléletú idézése szolgált alapul az erdélyi tơrténelmi drámának a XX. század mảsodik fele elsỏ két évtizedében. Habár Kossuth alakja kőzvetlenül nem jelenik meg Bocskỏi Viktor: Szabadság, szerelem (bemutatták 1948ban), Horváth Ágoston: Varga Katalin (bemutatták 1955-ben), Sombori Sándor: Gábor Áron (bemutatták: 1969-ben) történelmi színmüvekben, közős ideológiai alapjuk a lánglelkủ forradalmár népi felkelésre építő eszménye. A hely szellemének hagyományai értelmében ezek a drámák is a múltat nézik, a jeient látják és a jövendőt kémlelik. Csakhogy mig az első két dráma a vulgár történelmi materializmus szemlélete szerint villantja fel hösei (Petöfi, Varga Katalin) sorsát, a "a forradalmi jelen" soros pártideológiảját hirdető mủvekkẻ degradálva a színmủveket, addig Sombori írása a felszínre tơrö nemzeti önismeret igényét fejezi ki, a közösségi megmaradást szolgáló alkotások sorát gazdagítja.

A XX. századi történelmi drámavonulatból a kossuthi eszmekörhöz a közösséginemzeti érzés ébren tartóiként, a nemzeti tudat formálóiként számon tartott Németh László és Illyés Gyula színpadi mủvészete kapcsolódik leginkább. 
Illyés történelmi drámaciklust írt múltunk sorsfordító pontjairól, megidézve 1514, 1849, 1945 példáit. A ciklus kiemelkedö darabja a Fáklyaláng. A tragikus feszültségü konfliktus Kossuth és Görgey között bomlik ki közvetlenül a világosi fegyverletételt megelözö idöszakban, mikor a nemzet sorsa kettöjük kezébe helyezödött: mi szolgálja inkább a nemzeti érdeket, a harc folytatása vagy a megadás? Két nemzetkarakterológiai típus körvonalazódik: a lángoló, a csodahívö, az eszmények büvöltje és a reálpolitikusi. Egyik a kiáltványok igéit hatékonyabbaknak ítéli, mint az ágyúk igéit, a másik a matematikát tartja a háború fö tényezöjének. Az egyik szerint, aki ember, annak nincs gondolkodnivalója a becsület és a megadás között, egy választás van csak, a harc. A másik szerint ötvenezer nem győzhet háromszázezer fölött. A Fáklyaláng az első típusú hös apologetikája. Illyés azoknak adja a pálmát, akik földi erővel mennyei dolgokon fáradoznak, akik Isten dolgába merészelnek bele nyúlni. Az utójátékban az idö távlatával igazolja Kossuthot: „...Most már kiviláglott: érdemes lett volna a harc kockázata. Komárom reménytelen ellenállással is feltételeket csikart ki!...Lehetett volna folytatni, ha ö..." Görgey ,... fölött az idỏ itélt."

Szervesen illeszkedik ebbe a szemléletbe, az örökké létezö erdélyi Kossuth kultusz bizonyítékaként, a Fáklyaláng 1954. október 13-i bemutatója a marosvásárhelyi Székely Színházban. Az elöadás az erdélyi magyar színjátszás legendái közé tartozik. Nemcsak maga Illyés Gyula nyilatkozott elragadtatással az elöadásról, hanem az a több ezer nézö is, aki valóságos zarándoklatként sereglett Erdély minden részérỏl Marosvásárhelyre megtekinteni az elöadást. A siker magyarázata az, hogy az előadás egyrészt a személyi kultusz rabságából ébredezö közösség elementáris szabadságvágyának adott teret, amelyet Kossuth függetlenséget és az egyén felszabadítását hirdető szellemisége testesített meg, másrészt a müvészi interpretáció kivételesen magas színvonala. A kossuthi szellem megidézésének szándékát már a bemutató idöpontja is jelzi: alig egy héttel az aradi vértanúk kivégzésének évfordulója után kerül színre az a darab, amelynek első két felvonása az aradi vár kazamatáiban játszódik. Kossuthot Kovács György, Görgeyt Lohinszky Loránd alakította a Szabó Ernő rendezte elöadásban. E három név mára az egyetemes magyar színjátszás értékei közé emelkedett, a nemzet színészei közé tartoznak. Szabó Ernő elemzỏ készsége, színpadi feszültségteremtö ereje kiválóan szolgálta a két vitázó fél bonyolult lelki folyamatokat, vajúdásokat, történelmi döntéseket vállaló konfliktusának érvẻnyesülését. Az előadás hatásfokát rendkívüli mértékben emelte Andrási Márton nagyszerủ Józsa alakítása. Ha a darab gondolati ívében a Józsa szerepe csak színezỏ elemként van jelen, ( tulajdonképpen a szerzö engedménye az ötvenes évek népi demokratikus ideológiájának) Andrási mégis oly színpadi hatással rajzolta meg a figurát, hogy a nézöi emlékezetben a Köszívủ ember Pál huszára óta hozzá mérhetỏ népi figura nem maradt fenn.

Köztudatunkban Görgey neve analóg fogalom lett az árulóéval. Vörösmarty Mihály verse közszájon forgott:

„Görgeynek hívják a silány gazembert

Ki e hazát eladta cudarul

Kergesse őt az Isten haragia

A síron innen $\mathrm{s}$ a síron túl.

Kergesse ôt a balszerencse mint

Szilaj kutyák a felriadt vadat

Éljen nyomorbul s kinbul mind halálig

És ha elhal, verje meg a kárhozat..."

A Kossuth apologetikával szemben Németh László Az áruló címü drámájában kisérletet tesz arra, hogy a ", tett motívumát nem a lélekben, a históriában kell keresni" 
kiindulópontból vizsgálva Görgey történelmi szerepvállalását, nem csak perújrafelvételt érjen el, hanem Kossuth alakját a legendák szférájából a történelmi reáliák síkjába helyezze. A Fáklyalánggal szemben nem is a hagyományos konfliktusos drámamodellt alkalmazza, hanem a középpontos drámaszerkesztést. Ezt a dramaturgiai szemléletet Németh László dramaturgiája címủ tanulmányában Osváth Béla így jellemzi: „, Németh László Ibsent tartja a megújító erőnek, akiből meríteni kell. Mint Ibsen s elötte a görögök vagy Racine, a cselekmény szívének kivágására törekszik, $s$ ebben vonja össze, ami elötte történt, $s$ ami még történhetik. Így azután kevés alkalom nyílik a külsỏ cselekmény számára, de annál több lehetőség a belső harc, a jellem útjának, a lélek vívódásának megmutatására." Alkalom teremtödik arra, hogy Görgey is elvégezze önvizsgálatát: , Kossuthtal még egy éjszakára sem cserélném el a magam erkölcsiségét, mert nem lennék biztos: nem feküdnék-e ki egy nő ágyában megbízást, nem hazudnék-e a baritonomtól megmámorosodva olyan irtózatost, valamely vármegyeház erkélyéröl, hogy azt holtomiglan szégyellnem kellene." Így már valóban az egykori harcostársak elvi vitájáról van szó, s a Németh dráma a nemzeti önismeret perújrafelvételévé válik. A drámát olvasva visszaköszön mindaz, ami a nemzethalál víziójával küszködök, a Vörösmartyk, a Kölcseyek, a Csoórik, a Szilágyi Domokosok verseiböl kicsap, az önkorbácsoló indulat, a tragikus félelem, hogy eltününk a föld színéröl, vagy a nemzetféltés másik modus vivendije, a Csokonaiaké és a Zrínyiké, akik azt hírelik, hogy "nincs sír, hol egy nemzet süllyed el”, és „, egy népnél sem vagyunk alábbvalók".

Így válik a két dráma történelmi szerepek tükörképeivé. A Németh László-i dilemmafeloldás végsö fokon bölcs és megszivlelendö: „a döntö az, hogy kinek a viselkedésében ismer, akármi a forrása, a nemzet önmagára."

Úgy gondolom a kossuthi életmodell ezt üzeni a ma embere számára a színházon keresztül.

\section{Epilógus}

Habár szakmám szerint Kossuth és a színház kapcsolatáról kellett szólnom, kérem, engedjék meg, hogy közéleti tisztem folytán emlitsem az 1848-as forradalom szellemi atyja és az Erdélyi Magyar Közmủvelödési Egyesület közötti szoros kapcsolatot is.

$\mathrm{Az}$ 1885-ben alapitott testület célja az volt, hogy müködési körében a hazafiasságot fejlessze a nemzeti irányú mủvelődés által, nemzetépítő és megtartó egyesületté váljék. Kossuth Lajos, aki az emigráció éveiben is számon tartott minden honi megmozdulást, amely beilleszkedett nemzetmentő stratégiájába, Turinból küldött táviratában helyesli a szervezkedést, kéri az április 12-i alakuló közgyülés résztvevöit, hogy nyilvánítsák alapító tagnak, s mellékeli a 100 forintos dijat. Így a 48-as szellem ápolását alapvetỏ feladatának tekintette az EMKE, s létrehozta Kolozsvárt az 1848-as Ereklyemúzeumot. Jellemzö adat, hogy megnyitójára 1892. szeptember 18-án, Kossuth Lajos születésnapján került sor. A forradalom és szabadságharc tárgyi emlékeit, dokumentumait őrző múzeumot 1930-ban bezáratta a város vezetösége, anyagát ládákba csomagolva Sándor József fôtitkár hivatalába szállitották, aki a legérdekesebb anyagokat ott ki is állította. Fó helyre a turini remete adománya került: a Kossuth-asztal, egy fehér oszlopokon nyugvó márványasztalka. Egyértelmủen jelzi az EMKE szellemiségét, hogy szentélyében a helyiséget a Kossuth asztalka uralta.

Tulajdonképpen a Kossuth-hüségünket bizonyító epilógus megírására az is kényszerített, hogy Kossuth Lajos születésének 200. évfordulójản hitet tehessünk nemzetépítő programja mellett, hisz meggyőződésünk: a Kossuth által kidolgozott Dunakonföderációs terv egy megegyezésen alapuló, egyenlöséget biztositó, önkormányzatra épülő államszövetségről, az egységesülő, modern Európának is alapvetése lehet. 